\title{
Pendekatan Saintifik dan Model Pembelajaran Kooperatif Tipe Teams Games Tournament untuk Meningkatkan Hasil Belajar Taktik dan Strategi Permainan Sepak Bola pada Peserta Didik Kelas XII SMA
}

\author{
Yustinus Ronaldo Patty Diaz ${ }^{{ }^{*}}$ \\ ${ }^{1}$ Jurusan Pendidikan Jasmani, Kesehatan, dan Rekreasi, Universitas Pendidikan Ganesha, Singaraja, Indonesia
}

\section{AR T I CLE I N F O}

Article history:

Received July 16, 2021

Revised July 25, 2021

Accepted October 20, 2021

Available online November 25, 2021

Kata Kunci:

Pendekatan Saintifik, Kooperatif Tipe TGT

Keywords:

Near Scientific, Cooperative Type TGT

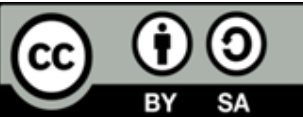

This is an open access article under the CC BY-SA license.

Copyright $(2021$ by Author. Published by Universitas Pendidikan Ganesha.

\begin{abstract}
A B S T R A K
Rendahnya hasil belajar siswa karena guru belum menjelaskan materi secara jelas dan lengkap. Guru mempratikkan gerakan terlalu cepat. Penelitian ini bertujuan menganalisis peningkatan hasil belajar taktik dan strategi permainan sepak bola melalui aplikasi pendekatan saintifik dan model pembelajaran kooperatif tipe TGT pada peserta didik kelas XII SMA. Penelitian ini adalah penelitian tindakan kelas yang dilaksanakan dalam dua siklus, yang terdiri dari rencana tindakan, pelaksanaan tindakan, observasi atau evaluasi dan refleksi. Subjek penelitian peserta didik kelas XII berjumlah 30 orang dengan rincian 13 orang putra dan 17 orang putri. Data dianalisis menggunakan statistik deskriptif. Hasil analisis data pada siklus I menunjukkan bahwa rata-rata nilai hasil belajar taktik dan strategi permainan sepak bola pada kompetensi sikap sebesar 80, pengetahuan 80 , dan kompetensi keterampilan sebesar 80 . Rata-rata nilai hasil belajar pada siklus II pada kompetensi sikap sebesar 85 , pengetahuan 85 , dan kompetensi keterampilan sebesar 85 . Ini berarti bahwa hasil belajar taktik dan strategi permainan sepak bola meningkat melalui aplikasi pendekatan saintifik dan model pembelajaran kooperatif tipe TGT pada peserta didik kelas XII SMA. Implikasi penelitian ini diharapkan dapat meningkatkan hasil belajar siswa.
\end{abstract}

\section{A B S T R A C T}

The low student learning outcomes are caused because the teacher has not explained the material clearly, and ultimately, the teacher practices the movement too fast. This study aims to analyze the increase in learning outcomes of soccer game tactics and strategies by applying a scientific approach and the TGT type cooperative learning model in class XII high school students. This research is classroom action research that is carried out in two cycles: an action plan, action implementation, observation or evaluation, and reflection. The research subjects of class XII students collected 30 people with details of 13 boys and 17 girls. Data were analyzed using descriptive statistics. The results of data analysis on the average value of learning outcomes for tactics and strategies in the first cycle of soccer games, namely at attitude competence of 80 , knowledge of 80 and skill competence of 80 , and the average value of learning outcomes in cycle II, namely at attitude competence of 85, knowledge of 85 and skill competency is 85 . Thus, the learning outcomes of soccer game tactics and strategies are increased by applying a scientific approach and the TGT type of cooperative learning model to students of class XII SMA. The implications of this research are expected to improve student learning outcomes.

\section{PENDAHULUAN}

Peningkatan mutu guru dan calon guru termasuk guru pendidikan jasmani olahraga dan kesehatan (PJOK) merupakan suatu hal yang mutlak harus diupayakan (Herlina \& Suherman, 2020; Raibowo et al., 2019). Guru yang bermutu dapat memberikan bekal kepada peserta didik agar dapat memenuhi tuntutan hidup dalam menyelesaikan masalah kehidupan sehari-hari dan masa yang akan datang (Herlina \& Suherman, 2020; Jumadi et al., 2021). Proses belajar yang baik yaitu mampu 
mengembangkan sikap ilmiah, proses ilmiah dan produk ilmiah dan diharapkan memicu hasil belajar siswa yang lebih tinggi (Aspa, 2020; Wicaksono et al., 2020). Namun kenyataannya, hasil belajar siswa di sekolah masih rendah. Berdasarkan observasi awal di SMA Negeri 2 Singaraja di kelas XII MIA 3 yang berjumlah 30 peserta didik yaitu 13 orang putra dan 17 orang putri, ditemukan hasil belajar taktik dan strategi permainan sepak bola peserta didik masih banyak yang belum tuntas dan perlu ditingkatkan. Data hasil belajar yang diperoleh yaitu kompetensi sikap sebanyak 26 orang $(81,25 \%$ ) tuntas dan 6 orang $(18,75 \%)$ belum tuntas. Hal ini menandakan bahwa masih ada peserta didik yang belum tampil bersih dalam belajar, mengganggu temannya belajar, datang terlambat, kurangnya kerja sama tim dalam belajar. Pada kompetensi pengetahuan, sebanyak 15 orang (46,875\%) tuntas dan 17 orang $(53,125 \%)$ belum tuntas. Hal ini terlihat dari kurangnya kemampuan peserta didik dalam menganalisis taktik dan strategi permainan sepak bola, kompetensi keterampilan sebanyak 14 orang (43,75\%) tuntas dan 18 orang $(56,25 \%)$ belum tuntas. Hal itu terlihat dari teknik dasar sepak bola yang belum sempurna, masih binggung dalam menerapkan taktik dan strategi, dan kerja sama dalam tim yang belum kompak. Guru belum menjelaskan materi secara jelas dan lengkap dan guru mempratikkan gerakan terlalu cepat. Guru hanya menyuruh siswa mempelajari buku siswa dan tidak menjelaskan secara lengkap. Guru hanya mendemonstrasikan gerakan sebagai contoh. Untuk mengatasi permasalahan yang ada, yang dilakukan yaitu menjelaskan materi secara jelas dan lengkap dengan berbantuan power point, mempraktikkan gerakan dibantu dengan pemutaran vidio pertandingan sepak bola. Namun masih banyak kendalakendala yang dihadapi peserta didik.

Solusi yang dapat diterapkan yaitu dengan mengombinasikan pendekatan saintifik dengan model pembelajaran kooperatif. Pendekatan ilmiah (scientific approach) dalam pembelajaran mencakup komponen: mengamati, menanya, mengumpulkan informasi, mengasosiasi, dan mengkomunikasikan (Novika Auliyana et al., 2018; Rahardjo, 2019; D. Setiawan, 2017). Model pembelajaran koperatif memerlukan pendekatan pengajaran melalui penggunaan kelompok kecil peserta didik untuk bekerja sama dalam memaksimalkan kondisi belajar dalam mencapai tujuan belajar (Kurniawati et al., 2017; Lestari, 2018; Lubis, 2020; Poerwati et al., 2020). Model pembelajaran kooperatif yang digunakan dalam memecahkan masalah tersebut adalah menggunakan model pembelajaran kooperatif tipe TGT. Penggunaan model TGT berpengaruh positif terhadap proses belajar mengajar, sehingga membantu tercapainya indikator keberhasilan (Barnaba \& Asruddin, 2018; Purwantini, 2013). Pendekatan saitifik dan model pembelajaran kooperatif tipe TGT akan dapat membantu peserta didik dalam pembelajaran. Peserta didik dapat menelaah mata pelajaran dan dapat mengaktualisasi diri serta kerja sama. Interaksi baik antara peserta didik dan guru akan membuat suasana pembelajaran tidak membosankan (Anggraeni \& Alpian, 2019; Novion, 2018; Wicaksono et al., 2020; Yun Ismi Wulandari, Sunarto, 2015). Adanya tim, permainan dan turnamen dalam pembelajaran kooperatif tipe TGT dapat menimbulkan rasa tanggung jawab peserta didik untuk memberikan kontribusi yang positif pada kelompoknya dan meningkatkan motivasi peserta didik untuk mengikuti proses pembelajaran, sehingga nantinya dapat berpengaruh terhadap peningkatan hasil belajar (Novion, 2018; Nurfajriah et al., 2021; Septiyan, 2017).

Beberapa temuan dari penelitian terdahulu menyatakan bahwa pendekatan saintifik pembelajaran menggunakan pendekatan saintifik memungkinkan untuk dipakai melatih literasi saintifik siswa (Narut \& Supradi, 2019; Setiawan, 2020). Pendekatan saintifik juga dapat meningkatkan keterampilan proses (Rahardjo, 2019). Pendekatan saintifik memberikan pengaruh terhadap prestasi belajar, kemampuan penalaran matematis dan minat belajar (Wibowo, 2017). Pendekatan saintifik dapat meningkatkan kreatifitas dan hasil belajar siswa (Alamsyah, 2017). Penerapan model kooperatif tipe Teams Games Tournament (TGT) keaktifan dan hasil belajar kognitif siswa (Anggraeni \& Alpian, 2019; Permatasari, 2017). Penerapan model kooperatif tipe Teams Games Tournament (TGT) juga dapat melatih keterampilan pengambilan keputusan (Septiyan, 2017). Penerapan pendekatan saintifik dan model kooperatif tipe Teams Games Tournament (TGT) sudah banyak dilaksanakan, namun belum ada penelitian yang mengkombinasik pendekatan saintifik dan model kooperatif tipe Teams Games Tournament (TGT). Maka, tujuan penelitian ini menganalisis penerapan aplikasi pendekatan saintifik dan model pembelajaran kooperatif tipe Teams Games Tournament (TGT) untuk meningkatkan hasil belajar taktik dan strategi permainan sepak bola pada peserta didik kelas XII SMA. Adanya penelitian ini diharapkan dapat meningkatkan hasil belajar siswa.

\section{METODE}

Jenis penelitian ini merupakan penelitian PTK. Penelitian ini dilakukan pada peserta didik XII MIA 3 SMA Negeri 2 Singaraja tahun pelajaran 2017/2018 pada semester ganjil dalam pembelajaran menganalisis, merancang, dan mengevaluasi taktik dan strategi Permainan sepak bola di lapangan olahraga SMA Negeri 2 Singaraja (Kanca I Nyoman, 2010: 146). Penelitian ini melibatkan kerja kolaborasi 
guru PJOK kelas XII dengan peneliti (Guru PPG SM-3T) dan partisipasi peserta didik kelas XII MIA 3 SMA Negeri 2 Singaraja yang berjumlah 30 peserta didik yaitu 13 orang putra dan 17 orang putri pada tahun pelajaran 2017/2018. Adapun prosedur PTK yaitu: (a) observasi awal, (b) refleksi awal, (c) identifikasi masalah, (d) analisis masalah, (e) perumusan masalah, (f) pelaksanaan tindakan, (g) observasi/evaluasi tindakan, dan (h) refleksi hasil tindakan.

Penelitian ini diawali dengan melakukan observasi awal di SMA Negeri 2 Singaraja pada hari/tanggal Sabtu, 24 September 2017 yang bertempat di Lapangan olahraga SMA Negeri 2 pada pukul 05.30 - 07.45 wita. Observasi awal dimaksudkan agar peneliti mendapat data awal tentang tempat yang akan dijadikan tempat penelitian. Siklus I terdiri atas empat komponen, yaitu: (1) perencanaan tindakan, (2) pelaksanaan tindakan, (3) observasi/evaluasi, dan (4) refleksi. Perencanaan tindakan siklus I yaitu menyusun rencana pelaksanaan pembelajaran (RPP) sesuai dengan permasalahan observasi awal yaitu materi taktik dan strategi permainan sepak bola, menyiapkan model pembelajaran yaitu aplikasi pendekatan saintifik dan model pembelajaran kooperatif tipe TGT dengan topik pembahasan yaitu materi taktik dan strategi permainan sepak bola, membentuk kelompok-kelompok yang beranggotakan 5 orang, dari 30 orang di bagi menjadi 6 kelompok, menyiapkan sarana dan prasarana yang dibutuhkan dalam proses pembelajaran taktik dan strategi permainan sepak bola yaitu: bola, kun, gawang, serta menyiapkan instrumen, format lembar penilaian hasil belajar taktik dan strategi permainan sepak boal.

Berdasarkan hasil refleksi dari siklus I, maka disusun perencanaan pembelajaran untuk menuntaskan hasil pembelajaran pada siklus II. Pada siklus II terdiri atas empat komponen, yaitu: (1) rencana tindakan, (2) pelaksanaan tindakan, (3) observasi/evaluasi, dan (4) refleksi. Berdasarkan refleksi dari siklus I, maka alternatif pemecahan masalah yang telah teridentifikasi, yaitu memperbaiki RPP sesuai dengan permasalahan observasi awal yaitu materi taktik dan strategi permainan sepak bola, mengidentifikasi permasalahan-permasalahan yang berkaitan dengan materi taktik dan strategi permainan sepak bola yaitu terutama dalam menganalisi video, teknik, dan peraturan permainan sepak bola, menyiapkan model pembelajaran yaitu aplikasi pendekatan saintifik dan model pembelajaran kooperatif tipe TGT dengan topik pembahasan yaitu materi taktik dan strategi Permainan sepak bola. Membentuk kelompok-kelompok yang beranggotakan 5 orang, dari 30 orang di bagi menjadi 6 kelompok, menyiapkan sarana dan prasarana yang dibutuhkan dalam proses pembelajaran taktik dan strategi permainan sepak bola yaitu: 6 buah bola, peluit, stopwacth, kamera, memperbaiki media pembelajaran dengan memperbanyak jumlah dan memperjelas media pembelajaran (video dan gambar), serta menyiapkan instrumen, format lembar penilaian hasil belajar taktik dan strategi permainan sepak bola. Penilaian kompetensi sikap didasarkan pada perilaku yang ditunjukkan peserta didik selama proses pembelajaran dengan menggunakan lembar pengamatan oleh peneliti yang dilakukan pada siklus I dan siklus II dengan menggunakan lembar pengamatan penilaian kompetensi pengetahuan dilakukan oleh peneliti sendiri pada akhir pembelajaran inti dengan menganalisis video permainan sepak bola dilakukan pada siklus I dan siklus II berupa pelaporan. Penilaian kompetensi keterampilan didasarkan pada perilaku yang ditunjukkan peserta didik selama proses pembelajaran dengan menggunakan lembar pengamatan oleh peneliti yang dilakukan pada siklus I dan siklus II dengan menggunakan lembar pengamatan. Teknik analisis menggunakan analisis kuantitatif.

\section{HASIL DAN PEMBAHASAN}

\section{Hasil}

Berdasarkan analisis data hasil belajar pada observasi awal materi taktik dan strategi Permainan Sepak bola, diperoleh data seperti dalam Tabel 1,2 dan 3. Berdasarkan Tabel 1 dapat dijelaskan bahwa peserta didik yang berada pada kriteria sangat baik 5 orang, baik 21 orang, dan cukup 4 orang dan tidak ada yang berada pada kriteria kurang. Rata-rata nilai hasil belajar kompetensi sikap secara klasikal yaitu 84, berada pada 80-90 dengan kriteria Baik atau predikat B, tetapi belum memenuhi ketuntasan belajar secara klasikal mencapai 100\%. Berdasarkan Tabel 2 dapat dijelaskan bahwa peserta didik yang berada pada kreteria sangat baik tidak ada, baik 15 orang, cukup 15 orang dan tidak ada yang berada pada kriteria kurang. Rata-rata nilai hasil belajar kompetensi pengetahuan secara klasikal yaitu 76 , berada pada rentang 70 - 79 dengan kriteria Cukup atau predikat C dan belum memenuhi ketuntasan belajar secara klasikal 100\%. Berdasarkan Tabel 3 dapat dijelaskan bahwa peserta didik yang berada pada predikat sangat baik 2 orang, baik 12 orang, cukup 16 orang dan tidak ada yang berada pada kriteria kurang. Ratarata nilai hasil belajar kompetensi keterampilan secara klasikal dapat yaitu 74, berada pada rentang 70 79 dengan kriteria cukup atau predikat $\mathrm{C}$ dan belum memenuhi ketuntasan belajar secara klasikal 100\%. Berdasarkan analisis data hasil belajar pada siklus I materi taktik dan strategi permainan sepak bola, diperoleh data pada Tabel 4, 5, dan 6. 
Tabel 1. Data Hasil Belajar Kompetensi Sikap

\begin{tabular}{cccccc}
\hline No & Jumlah Peserta Didik & Kriteria & Predikat & Presentase (\%) & Keterangan \\
\hline 1 & 5 & Sangat & A & $15,625 \%$ & 26 orang \\
2 & 21 & Baik & B & $65,625 \%$ & $(81,25 \%)$ \\
3 & 4 & Baik & B & $18,75 \%$ & 4 orang \\
4 & - & Cukup & C & - & $(18,75 \%)$ \\
Jumlah & $\mathbf{3 0}$ & Kurang & D & & $\mathbf{1 0 0 \%}$ \\
\hline
\end{tabular}

Tabel 2. Data Hasil Belajar Kompetensi Pengetahuan

\begin{tabular}{|c|c|c|c|c|c|}
\hline No & Jumlah Peserta Didik & Kriteria & Predikat & Presentase (\%) & Keterangan \\
\hline 1 & 0 & $\begin{array}{l}\text { Sangat } \\
\text { Baik }\end{array}$ & A & $0 \%$ & $\begin{array}{c}15 \text { orang } \\
(46,875 \%)\end{array}$ \\
\hline 2 & 15 & Baik & B & $46,875 \%$ & tuntas \\
\hline 3 & 15 & Cukup & $\mathrm{C}$ & $53,125 \%$ & 15 orang \\
\hline 4 & - & Kurang & $\mathrm{D}$ & - & $\begin{array}{c}(53,125) \text { belum } \\
\text { tuntas }\end{array}$ \\
\hline Jumlah & 30 & & & $100 \%$ & \\
\hline
\end{tabular}

Tabel 3. Data Hasil Belajar Kompetensi Keterampilan

\begin{tabular}{cccccc}
\hline No & Jumlah Peserta Didik & Kriteria & Predikat & Presentase (\%) & Keterangan \\
\hline 1 & 2 & Sangat Baik & A & $6,25 \%$ & 14 orang \\
2 & 12 & Baik & B & $37,5 \%$ & $(43,75 \%)$ \\
Tuntas \\
3 & 16 & Cukup & C & $56,25 \%$ & $\begin{array}{c}16 \text { orang } \\
(56,25) \text { belum } \\
4\end{array}$ \\
\hline Jumlah & - & Kurang & D & - & tuntas \\
\hline
\end{tabular}

Tabel 4. Data Hasil Belajar Kompetensi Sikap

\begin{tabular}{cccccc}
\hline No & Jumlah Peserta Didik & Kriteria & Predikat & Presentase (\%) & Keterangan \\
\hline 1 & 9 & Sangat Baik & A & $28,125 \%$ & 32 orang \\
2 & 21 & Baik & B & $71,875 \%$ & $(100 \%)$ tuntas \\
3 & - & Cukup & C & - & - \\
4 & - & Kurang & D & - & \\
\hline Jumlah & $\mathbf{3 0}$ & & & $\mathbf{1 0 0 \%}$ & \\
\hline
\end{tabular}

Berdasarkan Tabel 4. dapat dijelaskan bahwa, peserta didik yang berada pada kriteria sangat baik 9 orang (28,125\%), baik 21 orang (71,875 \%), dan tidak ada yang berada pada kriteria cukup dan kurang. Rata-rata hasil belajar kompetensi sikap pada siklus I secara klasikal yaitu 87 berada pada 80-90 dengan kriteria baik atau predikat B dan sudah memenuhi ketuntasan belajar secara klasikal mencapai $100 \%$. Berdasarkan Tabel 5 dapat dijelaskan bahwa peserta didik yang berada pada kriteria sangat baik 6 orang $(18,75 \%)$, baik 21 orang $(65,625 \%)$, cukup 3 orang $(15,625 \%)$, dan tidak ada yang berada pada kriteria kurang. Rata-rata nilai hasil belajar kompetensi pengetahuan pada siklus I secara klasikal yaitu 84 berada pada rentang 80 - 90 dengan kriteria baik atau predikat B, tetapi belum memenuhi ketuntasan belajar secara klasikal 100\%. Berdasarkan Tabel 6 dapat dijelaskan bahwa peserta didik yang berada pada predikat sangat baik 10 orang (31,25\%), baik 16 orang (50,00\%), 4 orang cukup (18,75\%), dan tidak ada yang berada pada kriteria kurang. Rata-rata nilai hasil belajar kompetensi keterampilan siklus I secara klasikal yaitu 85 berada pada rentang 80-90 dengan kriteria baik atau predikat B, tetapi belum memenuhi ketuntasan belajar secara klasikal 100\%. Penelitian siklus I pada kompetensi sikap sudah mencapai ketuntasan belajar 100\%, tetapi pada kompetensi pengetahuan dan keterampilan belum mencapai ketuntasan belajar 100\%. Dengan demikian pelaksanaan dalam penelitian ini dilanjutkan ke siklus II. Hasil dari refleksi siklus I akan digunakan sebagai referensi dalam melaksanakan penelitian pada siklus II dengan tujuan untuk dapat meningkatkan hasil belajar PJOK yang lebih baik. Berdasarkan analisis data hasil belajar pada siklus II dengan materi taktik dan strategi permainan sepak bola, maka dapat 
dikelompokkan kategori ketuntasan hasil belajar peserta didik seperti dalam Tabel 7, 8, dan 9. Berdasarkan Tabel 7 dapat dijelaskan bahwa peserta didik yang berada pada kriteria sangat baik 14 orang $(43,75 \%)$, baik 16 orang (56,25 \%), dan tidak ada yang berada pada kriteria cukup dan kurang. Rata-rata nilai hasil belajar kompetensi sikap secara klasikal yaitu 89 berada pada 80-90 dengan kriteria baik atau predikat B dan sudah memenuhi ketuntasan belajar secara klasikal mencapai 100\%. Berdasarkan Tabel 8. dapat dijelaskan bahwa peserta didik yang berada pada kriteria sangat baik 27 orang (84,375\%), baik 30 orang $(15,625 \%)$, dan tidak ada yang berada pada kriteria cukup dan kurang. Rata-rata nilai hasil belajar kompetensi pengetahuan secara klasikal yaitu 92 berada pada rentang 91-100 dengan kriteria sangat baik atau predikat A, dan sudah memenuhi ketuntasan belajar secara klasikal 100\%. Berdasarkan Tabel 9 dapat dijelaskan bahwa peserta didik yang berada pada predikat sangat baik 15 orang, baik 15 orang, dan tidak ada yang berada pada kriteria cukup dan kurang. Rata-rata nilai hasil belajar kompetensi keterampilan dapat dilihat pada Tabel 5, 6, 7 dan 8 .

Tabel 5. Data Hasil Belajar Kompetensi Pengetahuan

\begin{tabular}{|c|c|c|c|c|c|}
\hline No & Jumlah Peserta Didik & Kriteria & Predikat & Presentase (\%) & Keterangan \\
\hline 1 & 6 & $\begin{array}{l}\text { Sangat } \\
\text { Baik }\end{array}$ & $\mathrm{A}$ & $18,75 \%$ & \multirow{2}{*}{$\begin{array}{c}15 \text { orang } \\
(84,375 \%) \text { tuntas }\end{array}$} \\
\hline 2 & 21 & Baik & B & $65,625 \%$ & \\
\hline 3 & 3 & Cukup & $\mathrm{C}$ & $15,625 \%$ & \multirow{2}{*}{$\begin{array}{c}3 \text { orang } \\
(15,625) \text { belum } \\
\text { tuntas }\end{array}$} \\
\hline 4 & - & Kurang & $\mathrm{D}$ & - & \\
\hline Jumlah & 30 & & & $100 \%$ & \\
\hline
\end{tabular}

Tabel 6. Data Hasil Belajar Kompetensi Keterampilan

\begin{tabular}{|c|c|c|c|c|c|}
\hline No & Jumlah Peserta Didik & Kriteria & Predikat & Presentase (\%) & Keterangan \\
\hline 1 & 10 & $\begin{array}{l}\text { Sangat } \\
\text { Baik }\end{array}$ & $\mathrm{A}$ & $31,25 \%$ & \multirow{2}{*}{$\begin{array}{c}26 \text { orang } \\
(81,25 \%) \text { tuntas }\end{array}$} \\
\hline 2 & 16 & Baik & B & $50,00 \%$ & \\
\hline 3 & 4 & Cukup & $\mathrm{C}$ & $18,75 \%$ & \multirow{2}{*}{$\begin{array}{c}4 \text { orang } \\
(18,75) \text { belum } \\
\text { tuntas }\end{array}$} \\
\hline 4 & - & Kurang & - & - & \\
\hline Jumlah & 30 & & & $100 \%$ & \\
\hline
\end{tabular}

Tabel 7. Data Hasil Belajar Kompetensi Sikap

\begin{tabular}{cccccc}
\hline No & Jumlah Peserta Didik & Kriteria & Predikat & Presentase (\%) & Keterangan \\
\hline 1 & 14 & Sangat Baik & A & $43,75 \%$ & 30 orang \\
2 & 16 & Baik & B & $56,25 \%$ & $(100 \%)$ tuntas \\
3 & - & Cukup & C & - & - \\
4 & - & Kurang & D & - & \\
\hline Jumlah & $\mathbf{3 0}$ & & & $\mathbf{1 0 0 \%}$ & \\
\hline
\end{tabular}

Tabel. 8. Data Hasil Belajar Kompetensi Pengetahuan

\begin{tabular}{cccccc}
\hline No & Jumlah Peserta Didik & Kriteria & Predikat & Presentase (\%) & Keterangan \\
\hline 1 & 27 & Sangat Baik & A & $84,375 \%$ & 30 orang \\
2 & 3 & Baik & B & $15,625 \%$ & $(100 \%)$ tuntas \\
3 & - & Cukup & C & - & - \\
4 & - & Kurang & D & - & \\
\hline Jumlah & $\mathbf{3 0}$ & & $\mathbf{1 0 0 \%}$ & \\
\hline
\end{tabular}

Tabel 9. Data Hasil Belajar Kompetensi Keterampilan

\begin{tabular}{cccccc}
\hline No & Jumlah Peserta Didik & Kriteria & Predikat & Presentase (\%) & Keterangan \\
\hline 1 & 15 & Sangat Baik & A & $46,875 \%$ & 30 orang \\
2 & 15 & Baik & B & $53,125 \%$ & $(100 \%)$ tuntas \\
3 & - & Cukup & C & - & - \\
4 & - & Kurang & D & - & \\
\hline Jumlah & $\mathbf{3 0}$ & & & $\mathbf{1 0 0 \%}$ & \\
\hline
\end{tabular}




\section{Pembahasan}

Berdasarkan data hasil belajar tersebut dapat dinyatakan bahwa hasil belajar PJOK dari siklus I ke siklus II mengalami peningkatan. Penelitian pada siklus II sudah berhasil karena dari ketiga kompetensi yang nilai yaitu kompetensi sikap, pengetahuan dan keterampilan sudah memenuhi bahkan melewati standar KKM. Terjadinya peningkatan hasil belajar pada siklus II tersebut karena pengaplikasian pendekatan saintifik dan model pembelajaran kooperatif tipe TGT dengan pembelajaran berkelompok, games, dan turnamen sudah dipahami oleh peserta didik dan perbaikan berdasarkan kendala yang dialami. Meskipun pelaksanaan siklus II dinyatakan berhasil, tetapi masih terdapat kendala-kendala yang dihadapi saat pengaplikasian pendekatan saintifik dan model pembelajaran kooperatif tipe TGT, yaitu: terbatasnya waktu pelaksanaan penelitian sehingga peserta didik kekurangan waktu untuk lebih memahami tahapan-tahapan model pembelajaran yang peneliti terapkan. Dengan adanya kendala tersebut disarankan untuk selanjutnya gur agar lebih sering mengaplikasikan pendekatan saintifik dan model pembelajaran kooperatif tipe TGT dalam pembelajaran PJOK. Dengan demikian, peserta didik akan semakin paham dengan struktur pembelajaran dalam pengaplikasian pendekatan saintifik dan model pembelajaran kooperatif tipe TGT. Model pembelajaran kooperatif tipe TGT secara menarik dan menyenangkan yang membuat siswa lebih aktif dalam pembelajaran, sehingga hasil belajar siswa dan keaktifan siswa mengalami peningkatan. Kriteria keberhasilan ini dapat dilihat dari siswa yang lebih bersemangat dalam mengikuti pembelajaran karena adanya model dan media pembelajaran baru yang sebelumnya belum pernah diberikan oleh guru, siswa lebih mengetahui pentingnya belajar secara kelompok, siswa lebih memahami materi yang telah disampaikan, dan meningkatkan keaktifan serta hasil belajar siswa (L.E., 2018; Purwantini, 2013).

Peningkatan hasil belajar dalam penelitian ini tidak terlepas dari kelebihan-kelebihan pengaplikasian pendekatan saintifik dan model pembelajaran kooperatif tipe TGT yang menjadikan setiap peserta didik menjadi lebih siap dalam mengikuti pembelajaran, khususnya dalam pembelajaran PJOK. Model pembelajaran ini mengarahkan agar peserta didik yang pandai dapat mengajarkan peserta didik yang kurang pandai, sehingga secara otomatis peserta didik yang kurang pandai mendapatkan dampak yang positif. Dalam proses pembelajaran, peserta didik telah mampu belajar dan beraktivitas sendiri untuk memperoleh pengalaman, pengetahuan, pemahaman, dan tingkah laku lainnya, mampu bekerja sama dengan temannya, mengembangkan keterampilan yang dimiliki, serta sudah mulai sangat aktif dan antusias selama proses pembelajaran sehingga dapat memahami materi pelajaran dengan sangat baik (L.E., 2018; Novion, 2018).

Temuan ini diperkuat dengan penelitian sebelumnya yang menyatakan pendekatan saintifik pembelajaran menggunakan pendekatan saintifik memungkinkan untuk dipakai melatih literasi saintifik siswa (Narut \& Supradi, 2019; A. R. Setiawan, 2020). Pendekatan saintifik juga dapat meningkatkan keterampilan proses (Rahardjo, 2019). Pendekatan saintifik memberikan pengaruh terhadap prestasi belajar, kemampuan penalaran matematis dan minat belajar (Wibowo, 2017). Pendekatan saintifik dapat meningkatkan kreatifitas dan hasil belajar siswa (Alamsyah, 2017). Penerapan model kooperatif tipe Teams Games Tournament (TGT) keaktifan dan hasil belajar kognitif siswa (Anggraeni \& Alpian, 2019; Permatasari, 2017). Penerapan model kooperatif tipe Teams Games Tournament (TGT) juga dapat melatih keterampilan pengambilan keputusan (Septiyan, 2017). Dari pembahasan, kombinasi pendekatan saintifik dan penerapan model kooperatif tipe Teams Games Tournament (TGT) dapat diterapkan guru untuk meningkatkan hasil belajar taktik dan strategi permainan sepak bola. Selain itu pendekatan saintifik dan penerapan model kooperatif tipe Teams Games Tournament (TGT) dapat juga diterapkan pada pembelajaran lainnya. Implikasi penelitian ini diharapkan dapat meningkatkan hasil belajar siswa.

\section{SIMPULAN}

Aplikasi pendekatan saintifik dan model pembelajaran kooperatif tipe TGT dapat meningkatkan hasil belajar taktik dan strategi permainan sepak bola pada peserta didik. Pembelajaran dengan aplikasi pendekatan saintifik dan model pembelajaran kooperatif tipe teams games tournament mampu menunjang ketercapaian ketuntasan belajar, meningkatkan minat, semangat, serta motivasi belajar bagi seluruh peserta didik.

\section{DAFTAR RUJUKAN}

Alamsyah, N. (2017). Penerapan Pendekatan Saintifik untuk Meningkatkan Kreativitas dan Hasil Belajar Siswa dalam Mata Pelajaran IPA. Jurnal Pendidikan (Teori dan Praktik).

Anggraeni, S. W., \& Alpian, Y. (2019). Penerapan Metode Teams Games Tournament (TGT) untuk 
Meningkatkan Kemampuan Membaca Permulaan Siswa Kelas I Sekolah Dasar. Premiere Educandum: Jurnal Pendidikan Dasar Dan Pembelajaran, 9(2), 181.

Aspa, A. P. (2020). Pengaruh Daya Tahan dan Kecepatan terhadap Kinerja Wasit Sepak Bola C1 Nasional PSSI Provinsi Riau. Jurnal Pendidikan Jasmani Dan Olahraga, 3(2), 116-122.

Barnaba, \& Asruddin. (2018). Peningkatan Penguasaan Kosakata Bahasa Inggris melalui Media Anagram dalam Metode Kooperatif Tipe Teams Games Tournament Improving the English Vocabulary Mastery Through Anagram Media in Cooperative Methods of Study Teams Games Tournament Type. Jurnal Prima Edukasia, 2(1), 80-89.

Herlina, H., \& Suherman, M. (2020). Potensi Pembelajaran Pendidikan Jasmani Olahraga dan Kesehatan (Pjok) di Tengah Pandemi Corona Virus Disease (Covid)-19 di Sekolah Dasar. Tadulako Journal Sport Sciences And Physical Education, 8(1),

Jumadi, F., Laksana, A. A. N. P., \& Prananta, I. G. N. A. C. (2021). Efektivitas Pembelajaran PJOK pada Teknik Dasar Passing Bawah Permainan Bolavoli Melalui Media Daring pada Masa Pandemi Covid-19. Jurnal Pendidikan Kesehatan Rekreasi, 7(2), 423-440.

Kurniawati, K. R. A., Budiyono, \& Saputro, D. R. S. (2017). Penerapan Model Pembelajaran Kooperatif Tipe Jigsaw san Numbered Heads Together Ditinjau dari Kecerdasan Interpersonal Siswa pada Pokok Bahasan Bangun Ruang Sisi Datar. Jurnal Pendidikan Matematika, 11(1), 15-28. https: //doi.org/10.22342/jpm.11.1.3948.15-28.

L.E., E. P. (2018). Cooperative Learning Dengan Model TGt (Teams Games Tournament) Materi Bilangan Bulat bagi Siswa Kelas IV Sekolah Dasar. Buana Matematika: Jurnal Ilmiah Matematika Dan Pendidikan Matematika, 7(2:), 85-88. https: //doi.org/10.36456/buana_matematika.7.2:.1048.8588.

Lestari, N. P. C. (2018). Penerapan Model Pembelajaran Kooperatif Tipe NHT Berbantuan Media Audio Visual untuk Meningkatkan Hasil Belajar IPA. Journal of Education Action Research, 2(4), 355. https: //doi.org/10.23887/jear.v2i4.16331.

Lubis, R. S. (2020). Pengaruh Penggunaan Model Pembelajaran Kooperatif Tipe Jigsaw terhadap Hasil Belajar Mahasiswa. AXIOM: Jurnal Pendidikan Dan Matematika, 9(2), 199-205. https: //doi.org/10.30821/axiom.v9i2.8735.

Narut, Y. F., \& Supradi, K. (2019). Literasi Sains Peserta Didik dalam Pembelajaran IPA di Indonesia. Jurnal Inovasi Pendidikan Dasar, 3(1), 61-69.

Novika Auliyana, S., Akbar, S., \& Yuniastuti. (2018). Penerapan Pembelajaran Tematik Terpadu di Sekolah Dasar. Jurnal Pendidikan: Teori, Penelitian, Dan Pengembangan, 3(12), 1572-1582. https://doi.org/10.17977/jptpp.v3i12.11796.

Novion, Z. (2018). Implementasi Model Pembelajaran Kooperatif Tipe Teams Games Tournament (TGT) untuk Meningkatkan Hasil Belajar Siswa pada Materi Menganalisis Teknik Dasar Passing Dalam Permainan Sepak Bola. Journal Sport Area, 3(1), $87 \quad$ - 93. https: //doi.org/10.25299/sportarea.2018.vol3(1).1412.

Nurfajriah, S., Netriwati, N., \& Widyastuti, R. (2021). Pengaruh Model Pembelajaran Teams Games Tournament Menggunakan Sandi Semaphore Pramuka terhadap Kemampuan Pemecahan Masalah Matematis Ditinjau dari Tipe Kepribadian Siswa. Jurnal Cendekia: Jurnal Pendidikan Matematika, 5(3), 3178-3189. https://doi.org/10.31004/cendekia.v5i3.825.

Permatasari, N. E. (2017). Peningkatan Hasil Belajar IPA Siswa Kelas 5 SD Menggunakan Model Pembelajaran Kooperatif Tipe TGT Berbantuan Media Gambar. Jpsd, 3(2), 96-104. https: //doi.org/10.30870/jpsd.v3i2.2131.g2695.

Poerwati, C. E., Suryaningsih, N. M. A., \& Cahaya, I. M. E. (2020). Model Pembelajaran Kooperatif Tipe Jigsaw II dalam Meningkatkan Kemampuan Matematika Anak. Jurnal Obsesi: Jurnal Pendidikan Anak Usia Dini, 5(1), 281-292. https://doi.org/10.31004/obsesi.v5i1.496.

Purwantini, J. (2013). Pengaruh Model Pembelajaran Tipe TGT Berbantuan Media Question Box terhadap Hasil Belajar Matematika Siswa Kelas V SD. Jurnal Ilmiah, 1(1), 1-10. https: //doi.org/10.23887/jjpgsd.v1i1.960.

Rahardjo, M. M. (2019). Implementasi Pendekatan Saintifik sebagai Pembentuk Keterampilan Proses Sains Anak Usia Dini. Jurnal Pendidikan Dan Kebudayaan, 9(2), 148-159. https://doi.org/https://doi.org/10.24246/j.js.2019.v9.i2.p148-159.

Raibowo, S., Nopiyanto, Y. E., \& Muna, M. K. (2019). Pemahaman Guru PJOK tentang Standar Kompetensi Profesional. Journal Of Sport Education (JOPE), 2(1), 10. https://doi.org/10.31258/jope.2.1.10-15.

Septiyan, G. D. (2017). Pengaruh Model Teams Games Tournament terhadap Keterampilan Pengambilan 
Keputusan dalam Pembelajaran IPS di Sekolah Dasar. Mimbar Sekolah Dasar, 4(1), 106-116. https: //doi.org/10.23819/mimbar-sd.v4i1.5547.

Setiawan, A. R. (2020). Pembelajaran Tematik Berorientasi Literasi Saintifik. Jurnal Basicedu, 3(2), 524532. https://doi.org/10.31004/basicedu.v4i1.298.

Setiawan, D. (2017). Pendekatan Saintifik dan Penilaian Auntentik untuk Meningkatkan Mutu Pembelajaran Pendidikan Agama Islam. AL-ASASIYYA: Journal Of Basic Education, 1(2). https://doi.org/10.24269/ajbe.v1i2.683.

Wibowo, A. (2017). Pengaruh Pendekatan Pembelajaran Matematika Realistik dan Saintifik terhadap Prestasi Belajar, Kemampuan Penalaran Matematis dan Minat Belajar. Jurnal Riset Pendidikan Matematika, 4(1), 1-10. https://doi.org/10.21831/jrpm.v4i1.10066.

Wicaksono, P. N., Kusuma, I. J., Festiawan, R., Widanita, N., \& Anggraeni, D. (2020). Evaluas Penerapan Pendekatan Saintifik pada Pembelajaran Pendidikan Jasmani Materi Teknik Dasar Passing Sepak Bola. Jurnal Pendidikan Jasmani Indonesia, 16(1), 41-54. https://doi.org/10.21831/jpji.v16i1.29774.

Yun Ismi Wulandari, Sunarto, dan S. A. T. (2015). Implementasi Model Discovery Learning dengan Pendekatan Saintifik untuk Meningkatkan Kemampuan Berpikir Kritis dan Hasil Belajar Siswa Mata Pelajaran Ekonomi Kelas XI IIS I SMA Negeri 6 Surakarta Tahun Pelajaran 2014/2015. Jurnal Pendidikan Bisnis Dan Ekonomi,

$1(5)$. https://jurnal.fkip.uns.ac.id/index.php/ptn/article/view/7275/5057. 